Yossi Kugler and Dafna Dolinko

\title{
"Antisemitism From Its Origins to the Present": An Online Video Course by Yad Vashem
}

In March 2018, Yad Vashem-The World Holocaust Remembrance Centerlaunched a free online video course dedicated to the topic of antisemitism. The course aims to explore and analyze the nature of this phenomenon, its development, and evolution from its origins until the present day.

\section{Creating an Online Video Course on Antisemitism}

The need to create a free online course that would be open to the wider public and that would provide a concentrated overview of this subject was one that became increasingly apparent to us at Yad Vashem over the past decade. Yet we also were aware that presenting over two millennia of complex history and delving into different cultures and societies would be challenging and beyond our scope of expertise. We therefore turned to fifty experts, filming them in Israel, Europe, and the United States. They include historians, sociologists, linguists, philosophers, and political scientists among others. These video interviews form the base for the total of approximately ten hours of short video lectures that comprise the course.

Taking this material and molding into a course was a challenge within itself. How could we best introduce such a plethora of subjects, providing learners with necessary historical contexts and a clear narrative? We ended up structuring the materials chronologically, having a presenter connect the different video lectures and providing the relevant background information.

\section{The Structure of the Course}

Titled "Antisemitism: From Its Origins to the Present," the course is divided into six lessons: the first three explore the origins of the phenomenon and its development until the Holocaust, while the last three examine contemporary antisemitism. 
In the first lesson "What is Antisemitism? Definitions and Origins," learners are first introduced to the general topic of hatred through a lecture by social scientist Ruth Wodak. The lesson then moves on to question whether there is a uniqueness to antisemitism and presents a discussion of the term itself. We then turn to explore the historical origins of the phenomenon, beginning with the ancient and early Christian worlds. This is done by historians Paula Fredriksen, John G. Gager, and Jeremy Cohen. ${ }^{1}$ Cohen then explores Augustine's "Doctrine of Jewish Witness," which provided a sort of safety net for Jews in the early medieval period and the reasons that brought about the escalation of antiJewish attitudes and actions during the late Middle Ages. ${ }^{2}$ Historian David Nirenberg also presents his analysis of anti-Judaism and its place in the Western tradition. ${ }^{3}$

The second lesson, "The Changing Face of Antisemitism," moves on to the modern era, examining how attitudes toward Jews were affected by the major religious, social, and political movements that were shaping Europe and the world at the time. Historian Judith Kalik begins the lesson with the early modern period, comparing anti-Jewish actions and sentiments in Western and Eastern Europe. Focusing on France, Pierre Birnbaum discusses the conflicting attitudes toward Jews that arose following the Enlightenment, which allowed for a more tolerant perception of them, on the one hand, but also for the rise of a certain hostility against them, on the other. Moving on to the late modern period, the lesson turns to explore the development of modern antisemitism, showing the ways in which it was impacted by processes and movements such as Jewish emancipation, nationalism, urbanism, and racism. These are discussed by Shulamit Volkov, Aviel Roshwald, as well as by other historians. ${ }^{4}$ The lesson then focuses on three regional case studies-Germany, France, and the Russian Empire-examining how modern forms of antisemitism developed and were expressed in these realms. Subjects such as the Dreyfus Affair and The Protocols of the Elders of Zion are discussed. The in-depth analyses of these regions and top-

1 Cf. J. G. Gager, The Origins of Anti-Semitism: Attitudes toward Judaism in Pagan and Christian Antiquity (New York: Oxford University Press, 1983), and P. Fredriksen, When Christians Were Jews: The First Generation (New Haven: Yale University Press, 2018).

2 As he presents in his studies: J. Cohen, The Friars and the Jews: The Evolution of Medieval AntiJudaism (Ithaca: Cornell University Press, 1982) and ibid., Living Letters of the Law: Ideas of the Jew in Medieval Christianity (Berkeley: University of California Press, 1999).

3 More on this in his seminal book: D. Nirenberg, Anti-Judaism: The Western Tradition (New York: W. W. Norton \& Company, 2013).

4 Cf. S. Volkov, Germans, Jews, and Antisemites: Trials in Emancipation (Cambridge: Cambridge University Press, 2006), and A. Roshwald, The Endurance of Nationalism: Ancient Roots and Modern Dilemmas (Cambridge: Cambridge University Press, 2006). 
ics are presented by historians such as Pierre Nora, Elissa Bemporad, and Yehuda Bauer.

As can be understood from the title of the third lesson- "Genocidal Antisemitism: From World War I to the Holocaust," the lesson deals with the volatile first half of the twentieth century, touching upon subjects such as the First World War, the Bolshevik Revolution, the Russian Civil War, examining both the events themselves and the effects they had on the development of antisemitism. A substantial part of the lesson is dedicated to the rise of Nazism to power, the place of antisemitism in Nazi ideology, and the Holocaust. A video lecture of the late Otto Dov Kulka presenting his analysis of Redemptive Antisemitism is included as part of this. ${ }^{5}$ The lesson ends with a short lecture by Alvin Rosenfeld in which he shows how many people had expected antisemitism to disappear from the public sphere following the Holocaust and the great disappointment that arose once it became clear that it had not. He focuses on the contemporary world, stating that the need to analyze and understand current-day expressions of antisemitism has become, without being melodramatic about it, rather urgent. $^{6}$

This statement brings the learners to the second half of the course and its fourth lesson-"Contemporary Antisemitism." The first part of the lesson examines antisemitism in the Far Right. Ruth Wodak defines this sphere and the place of antisemitism in it and explains the differentiation between the radical and the populist right. ${ }^{7}$ She continues by presenting current-day examples from Europe, and historian Juliane Wetzel discusses the populist-right and the philosemitic tendencies that can be found within it today, both in Europe and the United States. The recent rise of antisemitism in the United States is also explored. As part of this topic, Jeffrey Herf examines right-wing populism and conspiracy theories in this sphere. Dina Porat and Anthony Julius then turn to discuss Holocaust denial and distortion-its origins and current-day variants and manifestations. The latter half of the lesson is dedicated to the topic of antisemitism in the Far Left. British researchers Dave Rich and David Hirsh define this phenomenon,

5 The term expanded on by Saul Friedländer but which first appeared in Kulka's "Richard Wagner und die Anfänge des modernen Antisemitismus," Bulletin des Leo Baeck Instituts 16 (1961): 281-300.

6 An issue of course expanded on in: Alvin H. Rosenfeld, ed., Resurgent Antisemitism: Global Perspectives (Boomington: Indiana University Press, 2013).

7 For more on this see: R. Wodak, The Politics of Fear: What Right-Wing Populist Discourses Mean (London: Sage, 2015). 
its roots, and expressions. ${ }^{8}$ The complex issue of anti-Zionism is analyzed by Anita Shapira, Dave Rich, and Alvin Rosenfeld, while Elissa Bemporad and Jeffery Herf explore the historical development of the phenomenon in the Soviet Union and the Soviet Bloc. ${ }^{9}$ The lesson then examines the important topic of the boundary between antisemitism and legitimate criticism of the Israeli state, and it ends with an exploration of the allegations of antisemitism in the British Labour Party.

Keeping within the framework of the contemporary world, the fifth lesson, "The Islamic and Arab World," deals with antisemitism in this sphere today. To a certain extent it diverges from the chronological structure of the course, as it also goes back in time to the early days of Islam. Lectures by historians Meir Litvak, the late Esther Webman, Bassam Tibi, and Mark R. Cohen present the accepted historiographic approach, influenced greatly by the work of Bernard Lewis ${ }^{10}$, showing how antisemitism in this world is a modern phenomenon, one that appeared in the nineteenth century as a result of national and geopolitical changes and developments. ${ }^{11}$ The early days of Islam and the Islamic religious texts are examined, and the history of Jews under Arab rule is also discussed. The researchers show how the religious, social, and economic factors that led to the development of antisemitism in Christian Europe were absent in the Islamic world. The second part of the lesson analyzes the rise of antisemitism in this sphere, focusing particularly on Islamism in today's world, the place of Holocaust denial, The Protocols of the Elders of Zion, and the Iranian government..$^{12}$

8 Discussed in-depth in D. Hirsh, Contemporary Left Antisemitism (London: Routledge, 2018), and D. Rich, The Left's Jewish Problem (London: Biteback Publishing, 2016).

9 Cf. J. Herf, Undeclared Wars with Israel: East Germany and the West German Far Left, 19671989 (Cambridge: Cambridge University Press, 2016), and ibid., "The Anti-Zionist Bridge: The East German Communist Contribution to Antisemitism's Revival After the Holocaust," Antisemitism Studies 1, no.1 (Spring 2017): $130-56$.

10 One example being his seminal B. Lewis, Semites and Anti-Semites: An Inquiry into Conflict and Prejudice (New York: W. W. Norton, 1986).

11 For more on this see, for example, E. Webman, "From the Damascus Blood Libel to the 'Arab Spring': The Evolution of Arab Antisemitism,” Antisemitism Studies 1, no.1 (Spring 2017): 157206.

12 Subjects that are explored in their many works, including: B. Tibi, Islamism and Islam (New Haven: Yale University Press, 2012); E. Webman, "Adoption of the Protocols in the Arab Discourse on the Arab-Israeli Conflict, Zionism, and the Jews," in The Global Impact of the 'Protocols of the Elders of Zion', ed. E. Webman (London: Routledge, 2011), 175-95: and M. Litvak and E. Webman, From Empathy to Denial: Arab Responses to the Holocaust (New York: Columbia University Press, 2009). 
The sixth and final lesson of the course "Addressing Antisemitism," opens with an additional examination of the issue of differentiating between antisemitism and legitimate criticism of the State of Israel. The BDS Movement is also discussed. The lesson then turns to examine a major issue in the topic of contemporary antisemitism and in that of hatred in general-the world of the internet and social media. As there is no group that is not targeted or attacked in this sphere, the examination is done within the wider context of online hatred by information scientist and elected president of the Israel Internet Association Karine Nahon. ${ }^{13}$ The lesson then turns to an exploration of how antisemitism is being addressed in our world today in different realms, such as research, legislation, education, and more. Figures such as European Commission Coordinator on Combating Antisemitism, Katharina Von Schnurbein, Advisor to the British Government on Antisemitism, John Mann, and Prefect and Inter-ministerial Delegate for the Fight Against Racism, Anti-Semitism, and Anti-LGBT Hatred (DILCRAH) in France, Frédéric Potier, discuss how antisemitism and other forms of hatred are being confronted in the European Union, the United Kingdom, and France.

The course ends with a video in which different religious leaders and leading figures and thinkers such as the late Rabbi Lord Jonathan Sacks, Imam Sheikh Dr. Usama Hasan, Archbishop Pierbattista Pizzaballa, and Prof. Michael Walzer, contemplate and discuss if and how antisemitism and other forms of hatred and intolerance can be eradicated.

\section{Platforms and Scope}

As mentioned, the course is open to the wide public free of charge. It was initially launched on the British digital education platform FutureLearn and has since been launched on the American-based Coursera and on the Israeli Campus IL platforms. The presentation language is English, however there are Hebrew, Spanish, and French subtitles. German subtitles are currently being produced as well.

As of early 2021, over thirty thousand learners from dozens of countries from around the world have actively participated in the course. To these we can add hundreds of thousands of views of different video lectures from the course, up-

13 A major topic discussed by Nahon is that of "virality," based on her research on the topic, cf. K. Nahon and J. Hemsley, Going Viral (Cambridge: Polity, 2013). 
loaded to YouTube. The feedback received on the course so far has been extremely positive.

Each video lecture in the course is followed by a short suggested bibliographical list for those interested in expanding their knowledge on the discussed topic, and each unit also allows for learners to comment, share their thoughts, and interact with other learners as well as with the Yad Vashem moderators. Over one hundred thousand comments have been posted thus far. The vast majority of them have been respectful and to the point, following the guidelines and the codes of conduct put up by the different platforms.

The course was promoted by Yad Vashem as well as by different international institutions and organizations committed to confronting hatred and antisemitism. It has been used by different organizations and parties, particularly in the United Kingdom, as a means to educate their members on the topic of antisemitism. Thus there were several politicians from both the left and right wings of British politics accused of making antisemitic remarks who have attended the course. $^{14}$

\section{Reflecting on the Work Thus Far}

March 2021 marked the course's third year online. Reflecting on the process of both constructing and moderating this course, we believe we may be able to provide some insights and thoughts on teaching this topic, particularly in the online sphere.

First and foremost we learned the importance of a balanced approach. This was expressed in the way the topic of differentiating between antisemitism and legitimate criticism of the State of Israel is discussed in the course. We touched upon this topic twice in the second half of the course, with lectures by philosopher Michael Walzer, historian Yehuda Bauer, and researchers Dave Rich and Kenneth Marcus, among others. We also expand this issue further by showing how not every criticism of Jews, Judaism, or the Israeli state is necessarily antisemitic. This is done by presenting actual examples of cases that may appear antisemitic but are not necessarily so.

In the course it was also imperative for us to show how hatred in general, stereotypes, and preconceived notions should be identified and confronted,

14 See, for example, the following post made by Neale Hanvey, SNP member of parliament for Kirkcaldy \& Cowdenbeath: N. Hanvey, "Apology for Posts Was a Watershed Moment for Me," Jewish News Blog, issued June 9, 2020, accessed February 25, 2021, https://blogs.timesofisrael. com/apology-for-posts-was-a-watershed-moment-for-me/. 
alongside antisemitism. As previously mentioned we do point out the uniqueness of antisemitism - this is discussed early on in the course by Ruth Wodak, sociologist Michel Wiewiorka, philosopher Steven T. Katz, and historian Peter Hayes. However, we truly believe that disconnecting this topic from the wider issue of hatred would be both incorrect and misleading.

A major concern for us going into the course was how to discuss different cultures and societies, particularly when presenting complex elements and issues. Any forms of generalizations and simplifications should of course be avoided. We mentioned earlier the issue of Islamism. In this regard we attempted to follow the balanced and sensitive approach established by researchers such as the late Esther Webman, whose videos feature prominently in the lesson dealing with the Arab and Islamic world. ${ }^{15}$

In order to present a more critical standpoint we also tried to include references and viewpoints that question some of those discussed in the course. For example when dealing with the term "antisemitism" itself, it was important for us to show that there are those that do not necessarily accept it in the same way it is presented in the course, referencing David Engel's well-known article. ${ }^{16}$

From their reactions it seems that the learners have responded extremely well to this balanced approach. However as can be expected, presenting complexities in a massive online platform has its downsides. In-depth discussions that we are used to, from classrooms or seminars, are of course nearly impossible to have in this sphere. The interpersonal and intimate contact between fellow learners and between learners and instructors is one that is also limited. Therefore the ability to reach tens of thousands does, and can come at times at the price of more comprehensive and exhaustive debates and discussions.

Another issue we have come across is that of updating the course content. Whereas a university professor could update a course at any given moment, the online course format is pretty much a closed and final one. Yet as we well know, the phenomenon of antisemitism is one that continues to develop. We have therefore done our best of adding components and video lectures to the course as much as possible. Among others, we have updated the lecture dealing with antisemitism in the British Labour party, added lectures on the French Yellow Vest Movement and the recent rise of antisemitism in the United States, and presented a wider analysis of populism and antisemitism.

15 On Esther Webman's academic legacy cf. D. Porat, “Esther Webman, 1947-2020,” Antisemitism Studies 4, no. 2 (2020): 388-90.

16 Cf. D. Engel “Away from a Definition of Antisemitism," in Rethinking European Jewish History, ed. J. Cohen and M. Rosman (Oxford: Littman Library of Jewish Civilization, 2009), 30-53. 
Lastly, any attempt to deal with such a wide topic in one course does not allow for a full examination of all the complexities and issues this topic brings up. However we do believe that the course presents an important overview of major developments in the history of antisemitism, hopefully allowing learners to both learn new information, question their own preconceived notions on a variety of topics, and hopefully allow for some level of change to take place, both within the online sphere and within the real world.

The course can be accessed free of charge at https://www.yadvashem.org/ education/online-courses/antisemitism.html.

Yossi Kugler and Dafna Dolinko have led the production and content development of the online video course "Antisemitism: From Its Origins to the Present." They work together at the International School for Holocaust Studies at Yad Vashem. Yossi is a PhD candidate at Tel Aviv University, writing his dissertation about the Israeli attitudes toward antisemitism in the years 1948-1987. Dafna has completed her MA studies in Jewish History at the Hebrew University of Jerusalem.

\section{References}

Cohen, Jeremy. The Friars and the Jews: The Evolution of Medieval Anti-Judaism. Ithaca: Cornell University Press, 1982.

Cohen, Jeremy. Living Letters of the Law: Ideas of the Jew in Medieval Christianity. Berkeley and Los Angeles: University of California Press, 1999.

Engel, David. "Away from a Definition of Antisemitism." In Rethinking European Jewish History, edited by Jeremy Cohen and Moshe Rosman, 30-53. Oxford: Littman Library of Jewish Civilization, 2009.

Fredriksen, Paula. When Christians Were Jews: The First Generation. New Haven: Yale University Press, 2018.

Gager, John G. The Origins of Anti-Semitism: Attitudes toward Judaism in Pagan and Christian Antiquity. New York: Oxford University Press, 1983.

Hanvey, Neale. “Apology for Posts Was a Watershed Moment for Me.” Jewish News Blog. Issued June 9, 2020. Accessed February 25, 2021. https://blogs.timesofisrael.com/apolo gy-for-posts-was-a-watershed-moment-for-me/.

Herf, Jeffery. "The Anti-Zionist Bridge: The East German Communist Contribution to Antisemitism's Revival After the Holocaust." Antisemitism Studies 1, no. 1 (Spring 2017): $130-56$.

Herf, Jeffery. Undeclared Wars with Israel: East Germany and the West German Far Left, 1967-1989. Cambridge: Cambridge University Press, 2016.

Hirsh, David. Contemporary Left Antisemitism. London: Routledge, 2018.

Kulka, Otto Dov. "Richard Wagner und die Anfänge des modernen Antisemitismus." Bulletin des Leo Baeck Instituts 16 (1961): 281-300. 
Lewis, Bernard. Semites and Anti-Semites: An Inquiry into Conflict and Prejudice. New York: W. W. Norton, 1986.

Litvak, Meir, and Esther Webman. From Empathy to Denial: Arab Responses to the Holocaust. New York: Columbia University Press, 2009.

Nahon, Karin, and Jeff Hemsley. Going Viral. Cambridge: Polity, 2013.

Nirenberg, David. Anti-Judaism: The Western Tradition. New York: W. W. Norton \& Company, 2013.

Porat, Dina. "Esther Webman, 1947-2020." Antisemitism Studies 4, no. 2 (2020): 388-90.

Rich, Dave. The Left's Jewish Problem. London: Biteback Publishing, 2016.

Rosenfeld, Alvin H., ed. Resurgent Antisemitism: Global Perspectives. Bloomington: Indiana University Press, 2013.

Roshwald, Aviel. The Endurance of Nationalism: Ancient Roots and Modern Dilemmas. Cambridge: Cambridge University Press, 2006.

Tibi, Bassam. Islamism and Islam. New Haven: Yale University Press, 2012.

Volkov, Shulamit. Germans, Jews, and Antisemites: Trials in Emancipation. Cambridge: Cambridge University Press, 2006.

Webman, Esther. "Adoption of the Protocols in the Arab Discourse on the Arab-Israeli Conflict, Zionism, and the Jews." In The Global Impact of the "Protocols of the Elders of Zion', edited by Esther Webman, 175-195. London: Routledge, 2011.

Webman, Esther. "From the Damascus Blood Libel to the 'Arab Spring': The Evolution of Arab Antisemitism." Antisemitism Studies 1, no. 1. (Spring 2017): 157-206.

Wodak, Ruth. The Politics of Fear: What Right-Wing Populist Discourses Mean. London: Sage, 2015. 
